\title{
IMPLEMENTASI BAHASA POSITIF DAN SCREEN TIME MANAGEMENT DALAM MEMBANGUN KARAKTER TERBAIK ANAK
}

\author{
Amrina Rosyada, Agustina Ramadhianti
}

English Education Program, Faculty of Art and Language, Universitas Indraprasta PGRI

\begin{abstract}
Abstrak
Kegiatan pengabdian masyarakat ini adalah kelanjutan dari kegiatan yang pernah dilakukan sebelumnya tentang penggunaan Bahasa positif. Pengabdian kali ini dilaksanakan dengan lebih komprehensif yaitu dengan mempertimbangkan satu fenomena yang sedang marak dihadapi oleh para ibu yang memiki anak-anak generasi millennial, yaitu penggunaan gawai digital secara bijaksana. Kegiatan pengabdian ini dilaksanakan pada ruang lingkup informal yaitu kalangan para ibu di Yayasan Baitul Hasan Jagakarsa yang berjumlah sekitar 47 orang peserta. Tujuan dari diadakannya kegiatan pengabdian masyarakat ini adalah sebagai berikut: 1) mengetahui dan mengevaluasi implementasi Bahasa positif peserta; 2) mengetahui dan mengevaluasi penggunaan gawai digital di kalangan peserta; dan 3) menyusun acuan Bahasa positif dan penggunaan gawai digital dan bijaksana bagi para peserta. Dengan menggunakan instrumen kuesioner dan metode diskusi, kegiatan ini memperlihatkan bahwa sebagian besar dari para peserta telah mengimplementasikan penggunaan Bahasa positif dan mengatur penggunaan gawai cerdas oleh anak-anak dengan bijaksana. Namun demikian, masih terdapat peserta yang belum mengetahui cara mengimplementasikan Bahasa positif dan mengatur jadwal penggunaan gawai digital secara bijaksana. Oleh karena itu, dengan kegiatan ini, peserta mampu mengimplementasikan Bahasa positif dan mengatur jadwal penggunaan gawai digital bagi anak mereka dengan tepat. Dengan demikian, peran ibu dalam membangun karakter terbaik anak menjadi semakin berkualitas dan tidak tergantikan.
\end{abstract}

Keywords: bahasa positif, karakter terbaik anak, pengaturan penggunaan gawai digital

\begin{abstract}
This community service is the continuum of the previous activity on developing children's positive characters with the use of positive language. It is administered comprehensively by adding the current issue which is merely faced by the mothers of the millenium generation, the screen time management. Engaged by 47 participants of mothers in Yayasan Baitul Hasan Jagakarsa, this community service is determined to: 1) evaluate the implementation of positive language; 2) evaluate screen time management; and 3) formulate positive language guidelines and screen time management. By applying questionnaires and discussion method, findings show that most mothers in Yayasan Baitul Hasan Jagakarsa have implemented positive language and screen time management. Though, there are still some mothers who don't understand the positive language and the screen time management. Therefore, with this activity, mothers would be able to implement the positive language and the screen time management properly. In this way, mothers who are the real educators in putting the fundamental characters for children, would be more qualified and irreplaceable.
\end{abstract}

Keywords: positive language, children's best characters, screen time management

Correspondence author: Amrina Rosyada, 4mrin4@gmail.com, Jakarta, Indonesia

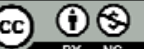

This work is licensed under a CC-BY-NC 


\section{PENDAHULUAN}

Yayasan Baitul Hasan Jagakarsa merupakan sebuah organisasi kemasyarakatan yang berbasis kegiatan agama Islam. Yayasan ini berdiri pada tahun 2017 sesuai dengan SK Kemenkumham Nomor: AHU-0002055.AH.01.04. Tahun 2017. Yayasan ini berdiri sebagai bentuk pengukuhan hukum dari Majelis Taklim Baitul Hasan, yang keberadaannya dibutuhkan oleh warga masyarakat sekitar sebagai naungan dan tempat ibadah yang bisa dijadikan learning-center bagi setiap lapisan masyarakat, mulai dari usia balita sampai dengan usia lanjut. Learning Center yang dimaksudkan adalah Learning Center yang berbasis Al Qur-an dan Al Hadist yang didukung dengan kemurnian proses pembelajarannya tanpa mengabaikan perkembangan ilmu pengetahuan yang terjadi di dalam kehidupan manusia. Dengan kebutuhan itu, yayasan ini membentuk dan menyusun struktur organisasi yang baku seperti bentuk yayasan pada umumnya, yaitu dipimpin oleh seorang Ketua Yayasan dan dibantu oleh Sekretaris dan Bendahara Yayasan, serta struktur penunjang lainnya.

Sebagai learning center, Yayasan Baitul Hasan Jagakarsa memiliki agenda acara yang sangat padat setiap harinya. Selain diisi dengan sholat berjamaah di setiap waktu sholat wajib, majelis ini juga menyelenggarakan program-program unggulan seperti Halaqah Tahfidz Qur'an Ma'had Baitul Hasan usia sekolah dasar sampai usia sekolah menengah atas setiap seminggu dua kali; pengajian cabe rawit bagi anak-anak usia balita sampai sekolah dasar setiap seminggu dua kali; pengajian remaja usia sekolah menengah pertama dan sekolah menengah atas setiap seminggu dua kali; pengajian khusus wanita setiap seminggu sekali dan seminar kewanitaan setiap sebulan satu kali; belajar dan latihan ilmu bela diri berupa ilmu bela diri silat bagi remaja usia sekolah menengah pertama ke-atas yang dilakukan setiap seminggu dua kali; dan programprogram lainnya.

Di antara begitu banyak kegiatan tersebut di atas, kegiatan pengajian wanita dilakukan secara rutin sebanyak satu kali dalam sebulan. Peserta pengajian wanita ini berasal dari beberapa kelurahan yaitu kelurahan Lenteng Agung, kelurahan Srengseng Sawah, kelurahan Ciganjur, dan kelurahan Jagakarsa. Materi yang disampaikan dalam pengajian ini bervariasi meliputi pengkajian Al Qur'an dan Al Hadist, ceramah umum dari ustadz atau ustadzah tertentu atau undangan, kajian kesehatan oleh pakar kesehatan, kajian psikologi islami oleh pakar psikolog, seminar keterampilan dan kerajinan tangan oleh pakar pengrajin, seminar wirausaha oleh pakar wirausahawan, dan kegiatankegiatan positif lainnya.

Mencermati kegiatan pengajian wanita dengan berbagai keilmuan, tim melihat masih banyak hal yang mendasar yang perlu untuk disampaikan kepada peserta, khususnya dalam hal pendidikan anak yang berkarakter. Pendidikan anak menjadi hal yang mendasar untuk diperhatikan mengingat anak adalah amanah sekaligus investasi masa depan yang akan dipertanggungjawabkan suatu hari nanti. Tanggung jawab ini tentunya berawal dari seorang ibu sebagai guru pertama sekaligus orang terdekat bagi anak sejak anak itu lahir ke dunia. Oleh karena itu, tim merasa penting bagi ibu untuk mengetahui dan mengimplementasikan Bahasa positif dalam proses pendidikan dan pendampingan anak-anak. Terlebih dengan semakin majunya teknologi, penggunaan Bahasa positif semakin tergantikan dengan berbagai media elektronik seperti televisi berlangganan dan gawai yang super canggih. Pemberian wawasan dan acuan yang jelas tentang penggunaan Bahasa positif dan penggunaan gawai secara berbatas dan bijaksana kepada para ibu akan sangat membantu para ibu dalam mempersiapkan karakter terbaik 
seorang anak. Peran ibu akan menentukan keberhasilan atau kegagalan anak di masa mendatang. Penggunaan bahasa positif dan pendampingan yang berkesinambungan dari seorang Ibu akan membentuk kepribadian yang juga positif pada seorang anak. Kekuatan Bahasa menjadi alat yang dahsyat bagi seorang Ibu, "lift the children up to the highest potential or tear them down”, (Denton, 2013).

Dalam masa observasi lapangan, terlihat beberapa permasalahan yang dihadapi oleh para ibu dalam mendidik dan membangun karakter terbaik anak. Ibu terlihat masih kurang memahami Bahasa positif sehingga mengalami kesulitan dalam mengimplementasikan Bahasa positif tersebut kepada anak. Selain itu, ibu juga terlihat kurang melakukan interaksi dan komunikasi dengan anak, terlebih dengan keberadaan gawai digital di rumah, menjadikan hubungan ibu dan anak semakin sulit. Lebih jauh lagi, antara ibu dan anak tercipta kesenjangan yang semakin jauh.

Berkaitan dengan permasalahan yang dihadapi oleh mitra, penggunaan bahasa yang tepat oleh seorang Ibu dan kedekatan Ibu terhadap anaknya akan sangat menentukan karakter yang melekat pada anak. Penggunaan positive language terbukti telah berhasil membangun karakter positif anak di banyak negara di Amerika dan Eropa. Salah satu peneliti yang telah membuktikan keberhasilan penggunaan positive language dalam membangun karakter positif anak adalah Sue Roulstone James Law, dkk (2010) yang melakukan penelitian terhadap anak-anak usia lima tahun pertama di wilayah Bristol, Inggris. Ia mengungkapkan bahwa penggunaan positive language dan membangun positive environment memberikan manfaat yang luar biasa dalam pembentukan karakter positif anak. Penelitian tersebut memberikan gambaran dan harapan bagi tim untuk dapat memberikan penyuluhan dan membantu para Ibu untuk dapat menerapkan kebiasaan berbahasa positif bagi anak-anak mereka, juga membangun emotional bonding kepada anak-anak mereka. Kebiasaan positif dan kedekatan emosi yang dibangun secara terus menerus terutama di masa lima tahun pertama diharapkan dapat membentuk lingkungan yang positif yang dapat menghasilkan generasi yang positif, yaitu generasi emas di masa depan (Claire, 2009).

Fungsi Bahasa bukanlah semata sebagai alat komunikasi, melainkan juga sebagai identitas yang tercermin dalam kepribadian seseorang. Seperti dinyatakan oleh BallJessica (2011, hal. 13), "Language is not only a tool for communication and knowledge but also a fundamental attribute of cultural identity and empowerment, both for the individual and the group." Ini menjelaskan bahwa penggunaan Bahasa oleh seseorang akan mencerminkan kepribadiannya.

Dalam penggunaannya, Bahasa yang digunakan oleh seseorang adalah Bahasa yang pertama kali ia ketahui dari orang yang paling dekat dengannya, yaitu ibu. Dalam perkembangannya, Bahasa ibu menjadi tolak ukur penggunaan Bahasa yang digunakan oleh seseorang. Seperti dijelaskan oleh Ball-Jessica (2011, hal. 13) bahwa:

"Mother tongue instruction generally refers to the use of the learners' mother tongue as the medium of the instruction. Additionally, it can refer to L1 as a subject of instruction. It is considered to be an important component of quality education, particularly in the early years. The experts view is that mother tongue instruction should cover both the teaching of and the teaching through this language."

Selain penggunaan bahasa, ada aspek-aspek lain yang juga sangat menentukan pembentukan karakter seorang anak. Pendekatan orang tua kepada anak-anak mereka akan sangat mempengaruhi karakter anak di masa mendatang. Lexmond-John dan 
Reeves-Richard (2009, hal. 31) menyatakan, "Parents' approach to their children-their level of warmth, responsiveness, control and discipline- are strongly influential on children's character capability development." Pernyataan tersebut menyebutkan aspekaspek lain yang juga harus menjadi perhatian bagi orang tua kepada anak-anak mereka. Membangun karakter anak bukanlah hal yang bisa dilakukan dengan mempertimbangkan satu aspek saja, melainkan dari berbagai aspek pendidikan seorang anak yang dilakukan secara komprehensif dan berkesinambungan sehingga anak bisa tumbuh dan memiliki karakter yang positif.

Dalam penelitian yang dilakukan oleh Amrina Rosyada dan Ayu Bandu Retnomurti (2016), para ibu terbukti tidak memahami peran ibu dan fungsi bahasa dalam keseharian mereka. Ibu tidak menyadari bahwa penggunaan bahasa positif yang tepat dalam keseharian mereka dapat membentuk karaketr anak yang sangat prinsip. Penggunaan bahasa positif yang dilakukan setiap hari, dapat memberikan pengaruh positif kepada anak. Namun sebaliknya, jika bahasa negatif yang digunakan, maka karakter negatif juga yang akan melekat pada anak. Dengan memberikan acuan bahasa positif yang sederhana, para ibu akhirnya dapat memahami dan menyadari bahwa menggunakan bahasa positif dalam keseharian mereka bukanlah hal yang sulit.

Penggunaan bahasa positif ini tidak hanya dapat digunakan di lingkungan keluarga, anatara ibu dan anak, tetapi juga di lingkungan formal sekolah, antara guru dan siswa. Hal ini dibuktikan oleh Amrina Rosyada, Ana Widyastuti, dan Agustina Ramadhianti (2018). Dalam peneltian tersebut, terbukti bahwa penggunaan bahasa positif dapat menciptakan lingkungan kelas yang kondusif dan membangun hubungan positif antara guru dan siswa. Dengan terciptanya hubungan positif anatar guru dan siswa serta terciptanya lingkungan belajar yang kondusif, maka tujuan dari pembelajaran dapat tercapai. Di satu sisi siswa dapat memahami dan menerima pelajaran dengan sangat baik, dan di sisi yang lain, guru dapat memberikan pembelajaran juga dengan sangat baik. Dengan demikian, penggunaan bahasa positif menjadi pilihan bagi siapa saja, baik di lingkungan formal, maupun di lingkungan informal, untuk dapat diimplementasikan sebagai alat untuk menciptakan suasana yang positif dan membangun karakter positif bagi anak maupun bagi siswa.

\section{METODE PELAKSANAAN}

Kegiatan pengabdian kepada masyarakat ini dilaksanakan selama kurun waktu September sampai dengan Desember 2018. Dalam kurun waktu tersebut dilaksanakan kegiatan yang meliputi: 1) persiapan kegiatan; 2) pelaksanaan kegiatan; 3) pengumpulan data; 4) evaluasi kegiatan; dan 5) penyusunan laporan kegiatan. Dengan melibatkan 48 peserta ibu-ibu, metode pelaksanaan yang digunakan dalam kegiatan ini adalah metode presentasi dan diskusi yang dilaksanakan dalam dua kali pertemuan atau seminar, yaitu seminar pertama pada tanggal 28 Oktober, dan seminar berikutnya pada tanggal 25 November. Selain metode presentasi dan diskusi, digunakan instrumen pendukung berupa pengumpulan data kuesioner yang meliputi informasi tentang penggunaan bahasa positif ibu di lingkungan keluarga dan penerapan manajemen waktu penggunaan gawai pintar bagi anak. Berdasarkan hasil pengumpulan data kegiatan seminar, baik yang berupa data hasil diskusi maupun data hasil kuesioner, kemudian dilakukan evaluasi data yang pada akhirnya disajikan dalam bentuk laporan kegiatan. 


\section{HASIL DAN PEMBAHASAN}

Pendidikan anak adalah hal yang mendasar untuk diperhatikan, mengingat anak adalah amanah sekaligus investasi masa depan yang akan dipertanggungjawabkan di hadapan sang pencipta. Berawal dari lingkungan terkecil dan terdekat yaitu keluarga, orang tua adalah sumber pendidikan utama dan pertama bagi anak. Interaksi di tahun pertama dengan orang tua dapat memberikan pengaruh menetap dan jangka panjang pada kematangan serta kesuksesan anak di kemudian hari. Oleh karena itu, orang tua diharapkan mampu melaksanakan perannya dalam mengimplementasikan pola asuh yang tepat bagi anak. Pola asuh orang tua akan menentukan perilaku anak, karena anak adalah peniru ulung. Tidak ada pemberian orang tua kepada anaknya yang lebih mulia daripada pendidikan yang baik.

Dalam keluarga, ibu memiliki peran yang sangat strategis sebagai madrasah atau sekolah bagi seluruh anggota keluarga. Jika sekolahnya baik, maka murid-muridnya juga akan baik. Proses pendidikan yang diberikan oleh seorang ibu sudah dimulai sejak anak masih dalam kandungan; bayi mendengarkan dan merasakan apa yang ibu dengarkan dan bacakan, juga apa yang ibu rasakan. Secara alamiah, peran ibu tidak akan pernah tergantikan; ketika menjalani masa hamil, menyusui, dan mengasuh, ibu juga membangun emotional bonding dengan anak.

Dalam kenyataannya, peran ibu di era revolusi industri 4.0 telah mengalami pergeseran. Ibu tidak lagi sepenuhnya menjadi sekolah bagi anaknya, karena peran ibu sebagai sekolah ini telah tergantikan oleh peran sekolah non-formal untuk anak-anak balita, atau peran ibu ini telah tergantikan oleh asisten rumah tangga yang secara nyata adalah orang lain bagi anak. Kenyataan ini tidak dapat dihindari karena tuntutan zaman yang mendorong ibu untuk berperan di luar rumah, menggantikan peran ayah, atau mendukung peran ayah yang dirasa masih kurang dalam hal finansial, atau bahkan ada juga yang lebih memilih sebagai wanita karier karena merasa peran ini jauh lebih bergengsi daripada hanya sekedar menjadi seorang istri dan ibu dalam keluarga.

Pergeseran peran ibu ini mengakibatkan perubahan sikap dan pola asuh pada anak. Ibu tidak lagi punya banyak waktu di dalam keluarga karena ibu mengalami kelelahan atau masih disibukkan dengan urusan pekerjaannya. Kondisi ini semakin diperparah dengan keberadaan teknologi canggih yang sangat menggiurkan bagi siapa saja, yaitu kehadiran gawai canggih yang berbentuk layar sentuh dengan beraneka tayangan yang menarik dan interaktif. Anak, kini tidak lagi membutuhkan ibu sebagai sekolah pertamanya, karena ibu telah memberikan peran itu kepada orang lain bahkan pada sebuah benda kecil yang bernama gawai cerdas.

Dalam kegiatan pengabdian kepada masyarakat ini, fakta menunjukkan bahwa peserta yang mengikuti kegiatan ini didominasi oleh para ibu yang berprofesi sebagai ibu rumah tangga. Dari total peserta yang mengikuti kegiatan ini yaitu sejumlah 48 orang ibu, sebanyak 43 orang ibu berprofesi sebagai ibu rumah tangga, 3 orang ibu berprofesi sebagai Pegawai Negeri Sipil, 1 orang ibu sebagai Guru Taman Kanakkanak, dan 1 orang ibu sebagai wira usaha. Latar belakang pendidikan yang dimiliki oleh para peserta sangat beragam, mulai dari lulusan sekolah dasar sampai dengan lulusan sarjana strata satu.

Untuk mendapatkan informasi tentang penggunaan bahasa positif dan media digital pada anak di lingkungan keluarga para peserta, kegiatan ini menggunakan kuesioner yang harus diisi pada saat kegiatan berlangsung. Setiap responden diberikan dua jenis kuesioner, yaitu satu kuesioner tentang penggunaan bahasa positif dan 
kuesioner berikutnya tentang penggunaan media digital bagi anak. Untuk kuesioner penggunaan bahasa positif, terdapat 6 acuan bahasa positif yang dijadikan ukuran, yaitu meliputi: 1) melakukan diskusi dengan anak dalam menetapkan aturan di rumah; 2) menghindari penggunaan kata "Jangan" kepada anak; 3) menggunakan kata "Tolong" ketika meminta bantuan kepada anak; 4) mau meminta maaf kepada anak ketika melakukan kesalahan atau lupa menunaikan janji kepada anak; 5) memberikan pujian positif kepada anak ketika anak melakukan hal-hal yang positif; dan 6) memberikan tanggung jawab di rumah kepada anak. Selain itu, untuk mengukur kedekatan ibu dengan anaknya, pada kuesioner ini juga menanyakan tentang seberapa sering ibu memeluk anaknya dalam satu hari.

Untuk kuesioner kedua berisi data tentang penggunaan media digital oleh anak. Untuk kategori ini, terdapat 2 kelompok informasi yang dirangkum, yaitu: 1) alasan pemilihan konten yang dilihat pada media digital; dan 2) durasi penggunaan media digital dalam satu hari. Untuk alasan pemilihan konten media digital, diuraikan ke dalam pilihan alasan pendidikan, hiburan, pengganti Ibu yang sibuk, pendidikan dan hiburan, hiburan dan pengganti ibu yang sibuk, dan komunikasi. Untuk durasi penggunaan media digital, diuraikan menjadi empat kelompok waktu, yaitu 0-1 jam, 1-2 jam, di atas 2 jam, dan tidak berbatas waktu.

Berdasarkan data yang terkumpul, informasi umum tentang responden dikelompokkan ke dalam dua kategori, yaitu pertama adalah para ibu yang memiliki anak-anak berusia di bawah 13 tahun, dan kedua adalah para ibu yang memiliki anakanak yang berusia di atas 13 tahun. Berdasarkan data dari 48 responden, terdapat 37 responden yang memiliki anak-anak berusia di bawah 13 tahun, dan 11 responden yang memiliki anak-anak berusia di atas 13 tahun. Untuk kategori pertama, responden termuda berusia 25 tahun dan tertua berusia 53 tahun; sementara untuk kategori kedua, responden termuda berusia 44 tahun dan tertua berusia 68 tahun.

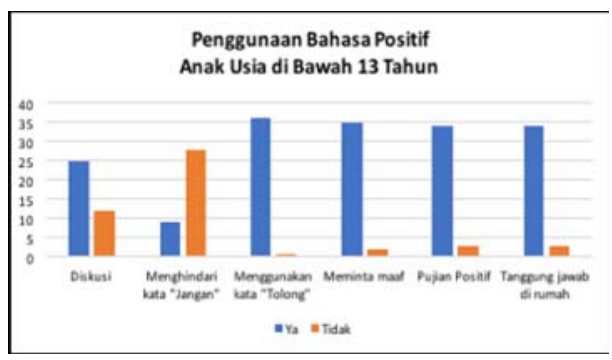

Gambar 1 Penggunaan Bahasa Positif Anak Usia di Bawah 13 Tahun

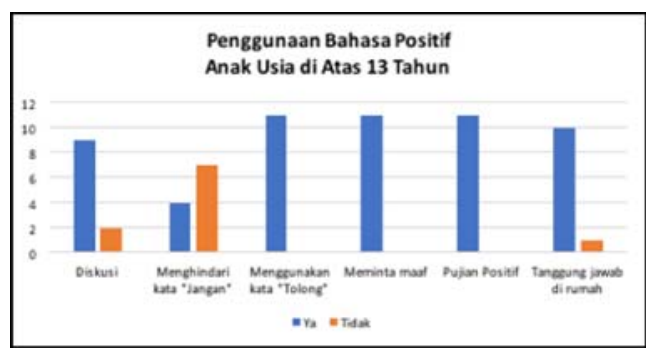

Gambar 2 Penggunaan Bahasa Positif Anak Usia di Atas 13 Tahun 
Gambar di atas adalah data yang telah dikumpulkan dan dirangkum dalam setiap kategori dan menunjukkan realitas yang cukup menggembirakan. Untuk penggunaan bahasa positif, baik untuk anak usia di bawah 13 tahun maupun anak usia di atas 13 tahun, menunjukkan bahwa terdapat $90 \%-100 \%$ dari responden yang telah menggunakan kata "Tolong", mau meninta maaf, memberikan pujian positif, dan memberikan tanggung jawab kepada anak-anaknya. Untuk berdiskusi dengan anak dalam memutuskan aturan-aturan yang harus dilaksanakan bersama, terdapat $68 \%$ dan $82 \%$ dalam pelaksanaannya. Sedangkan untuk menghindari kata "Jangan", harus diakui bahwa para responden masih sedikit yang melakukannya, yaitu hanya $24 \%$ untuk anak usia di bawah 13 tahun dan 36\% untuk anak usia di atas 13 tahun.

Sementara itu, untuk data penggunaan media digital, yang juga dikelompokkan ke dalam kategori anak usia di bawah 13 tahun dan usia anak di atas 13 tahun, dapat dilihat lebih rinci pada gambar diagram berikut.

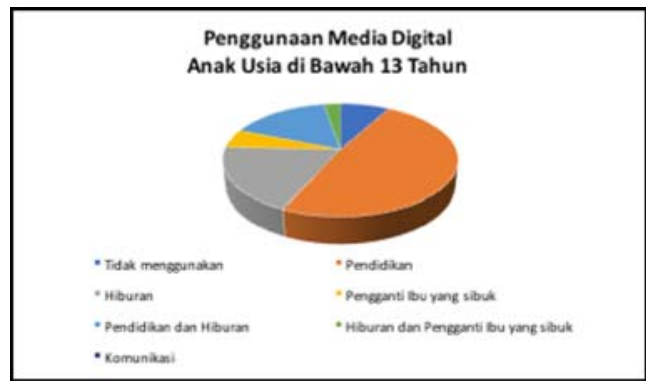

Gambar 3 Penggunaan Media Digital Anak Usia di Bawah 13 Tahun

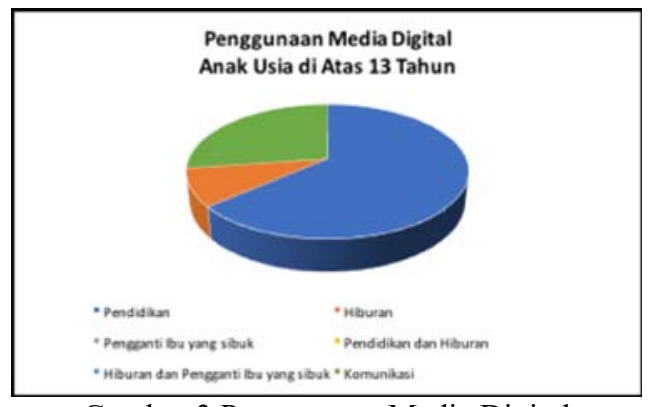

Gambar 3 Penggunaan Media Digital

Anak Usia di Atas 13 Tahun

Gambar di atas menunjukkan bahwa hanya 8\% dari responden yang memiliki anak usia di bawah 13 tahun, yang tidak memberikan ijin kepada anak-anaknya untuk menggunakan media digital, terutama yang berbentuk gawai cerdas. Pada umumnya, terdapat 49\% responden yang memiliki anak usia di bawah 13 tahun dan 64\% dari responden yang memiliki anak usia di atas 13 tahun, yang memberikan ijin kepada anak-anaknya untuk menggunakan media digital sebagai sarana pendidikan. Untuk alasan hiburan, hanya terdapat $19 \%$ dari responden yang memiliki anak usia di bawah 13 tahun yang memberikan ijin penggunaan media digital kepada anaknya, dan hanya $9 \%$ dari responden yang memiliki anak usia di atas 13 tahun.

Secara lebih rinci, penggunaan media digital tersebut diuraikan ke dalam durasi penggunaannya. Untuk anak usia di bawah 13 tahun, terdapat sekitar 22\% dari responden yang membiarkan anaknya menggunakan media digital selama kurang dari 
satu jam untuk alasan pendidikan; 39\% untuk penggunaan 1-2 jam; 17\% untuk penggunaan di atas 2 jam; dan $22 \%$ untuk penggunaan media digital yang tidak terbatas waktu. Untuk alasan hiburan, hanya $38 \%$ yang durasi penggunaannya maksimal 1 jam; $38 \%$ untuk penggunaan $1-2$ jam; $12 \%$ untuk durasi di atas 2 jam; dan $12 \%$ untuk durasi tidak berbatas. Sementara itu, untuk anak usia di atas 13 tahun, penggunaan terbanyak untuk alasan pendidikan dengan durasi 0-1 jam sebanyak 43\%; di atas 2 jam sebanyak $43 \%$, dan tidak terbatas sebanyak $14 \%$. Secara rinci, dapat dilihat pada gambar diagram yang disajikan sebagai berikut.
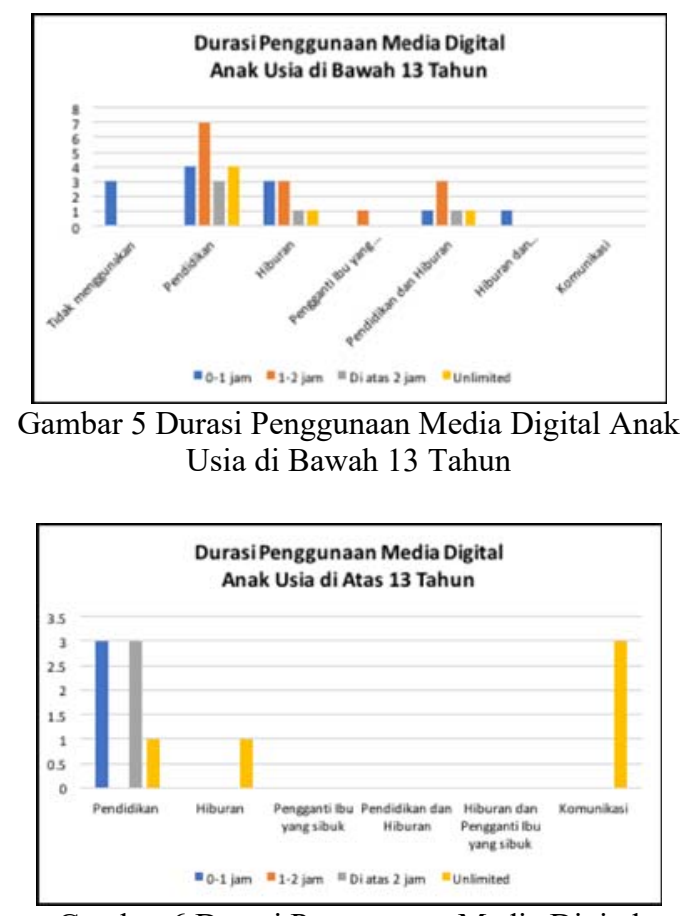

Gambar 6 Durasi Penggunaan Media Digital Anak Usia di Atas 13 Tahun

Berdasarkan data-data yang telah disajikan di atas, terlihat bahwa para peserta pada umumnya telah menerapkan prinsip-prinsip penggunaan bahasa positif dengan cukup baik. Sedangkan untuk penggunaan media digital secara bijak, terlihat bahwa para peserta masih pada ambang toleransi dalam menerapkan batas-batas penggunaan media digital secara wajar. Para peserta telah menyadari peran penting seorang ibu dalam menanamkan dasar-dasar karakter anak, baik dengan menggunakan bahasa positif secara berkesinambungan, maupun dalam penggunaan media digital secara bijak. Para ibu sangat memahami bahwa dunia boleh saja berubah dan berkembang begitu pesat, namun peran ibu sebagai tokoh utama dalam mendidik anak ada di tangan seorang ibu, dan peran ini tidak akan pernah tergantikan sepanjang masa.

\section{SIMPULAN}

Pelaksanaan program pengabdian kepada masyarakat ini pada dasarnya adalah memberikan wawasan yang luas kepada para peserta dalam mengubah pola pikir dan meningkatkan kemampuan berkomunikasi dan berinteraksi mereka. Berdasarkan hasil pelaksanaan program pengabdian kepada masyarakat ini, dapat disimpulkan bahwa 
pemberian materi tentang penggunaan Bahasa positif dan penggunaan gawai secara berbatas dan bijaksana bagi para ibu jamaah Yayasan Baitul Hasan Jagakarsa, telah memberikan wawasan baru bagi para peserta. Selain itu, pemberian materi tentang penggunaan Bahasa positif dan penggunaan gawai secara berbatas dan bijaksana bagi para ibu jamaah Yayasan Baitul Hasan Jagakarsa, telah memudahkan peserta dalam mengimplementasikannya dalam keluarga. Pada akhirnya, pemberian materi tentang penggunaan Bahasa positif dan penggunaan gawai secara berbatas dan bijaksana bagi para ibu jamaah Yayasan Baitul Hasan Jagakarsa, telah meningkatkan komunikasi dan interaksi para peserta dengan anak-anaknya di lingkungan keluarga.

\section{DAFTAR PUSTAKA}

Ball, J. (2011). Enhancing Learning of Children from Diverse Language Backgrounds: Mother Tongue-Based Bilingual or Multilingual Education in the Early Years. Paris, France: UNESCO.

Brogle, B. et al (2013). How to Use Positive Language to Improve Your Child's Behavior. Technical Assistance Center on Social Emotional Intervention. http://www.challenging behavior.org/

Claire, K. (2009). Language and Culture. Oxford, New York: Oxford University Press.

Denton, P. (2013). The Power of Our Words: Teacher Language that Helps Children Learn (Responsive Classroom). $2^{\text {nd }}$ Edition. Center for Responsive Schools, Inc.

Law, J. et al (2010). Investigating the Role of Language in Children's Early Educational Outcomes. Research Report on Department for Education, UK.

Lexmond, J. and Reeves, R. (2009). Building Character: Parents are the Principal Architects of a Fairer Society. First Published. London, UK: DEMOS.

Rosyada, A. and Retnomurti, A.B. (2017). The use of positive language on children education to build children's positive behavior. Scope, Journal of English Language Teaching, 1(1), 1-8.

Rosyada, A., Widyastuti, A., \& Ramadhianti, A. (2018). Implementation of positive language to promote effective language teaching classrooms for state junior high school. Lingua Cultura, 12(3), 241-246. https://doi.org/10.21512/lc.v12i3.4081 